\title{
Changes of T-lymphocyte subpopulation and differential expression pattern of the T-bet and GATA-3 genes in diffuse large B-cell lymphoma patients after chemotherapy
}

\author{
Qingsong Yin, Lin Chen, Qianyu Li, Ruihua Mi, Yufu Li, Xudong Wei and Yongping Song
}

\begin{abstract}
Background and objective: $T$ cell-mediated immunity plays an important role in enhancing antitumor response. This study aimed to investigate the changes in the T-lymphocyte subpopulation and to characterize the differential expression pattern of corresponding regulatory genes in peripheral blood mononuclear cells (PBMCs) from diffuse large $B$ cell lymphoma (DLBCL) patients before and after chemotherapy.

Methods: A total of 56 DLBCL patients were recruited for analysis of T-cell subset distribution in the peripheral blood using flow cytometry; serum interferon (IFN)- $\gamma$ and interleukin (IL)-4 levels using enzyme-linked

immunosorbent assays; and early growth response protein 1 (EGR-1), T-bet, GATA-binding protein 3 (GATA-3), and transforming growth factor (TGF)- $\beta$ mRNA levels using quantitative reverse-transcription polymerase chain reaction. Twenty-six healthy subjects served as controls.

Results: The percentage of $\mathrm{CD}^{+} \mathrm{CD}^{+} \mathrm{T}$ lymphocytes in peripheral blood from DLBCL patients was significantly decreased, whereas the percentages of $\mathrm{CD}^{+} \mathrm{CD}^{+} T$ and $C D 4^{+} \mathrm{CD} 25^{+} T$ cells were significantly increased compared to those in controls $(p<0.05)$. Serum levels of IFN- $\gamma$ and IL-4 were also significantly lower in $D L B C L$ patients than those in controls $(p<0.05)$, and the levels of EGR-1, T-bet, and GATA-3 mRNA in PBMCs were lower $(2.69 \pm 1.48$, $9.43 \pm 2.14$, and $20.83 \pm 9.05$ fold, respectively) in DLBCL patients than those in controls. Furthermore, there was a positive association between the levels of EGR-1 and T-bet mRNA $(p=0.001)$. However, the level of TGF- $\beta$ mRNA was significantly increased in DLBCL patients, which was inversely associated with the T-bet mRNA level $(p=0.008)$, but positively associated with the percentage of T regulatory cells in PBMCs $(p=0.011)$. After three cycles of chemotherapy, the distribution of T-lymphocyte subsets in DLBCL patients were changed, and the levels of EGR-1, T-bet, and GATA-3 mRNA were significantly increased $(p<0.05)$ compared to those before chemotherapy.

Conclusions: These results demonstrate the changes in T-lymphocyte subpopulations and the altered expression 34 pattern of the corresponding regulatory genes in PBMCs from DLBCL patients after chemotherapy, which are associated with the response of patients to treatment. The preferential expression of the T-bet gene after chemotherapy was closely correlated with the increased expression of the EGR-1 gene and decreased expression of the TGF- $\beta$ gene.
\end{abstract}

Keywords: Diffuse large B cell lymphoma, Th1/Th2, T-bet, GATA-3, Immunoregulation

\footnotetext{
*Correspondence: xudongwei@zzu.edu.cn

Henan Cancer Hospital, Henan Institute of Hematology, and Cancer Hospital

of Zhengzhou University, Zhengzhou, Henan, China
} 


\section{Background}

Diffuse large B cell lymphoma (DLBCL) is the most common type of non-Hodgkin lymphoma in adults and is an aggressive malignancy that can arise in any part of the body [1]. At present, the standard treatment for DLBCL is chemotherapy and combination treatment with an antibody-targeted therapy. Most patients do experience good survival with a curable rate of more than 70\% [2]. The precise mechanism of the development of DLBCL is not yet clear. However, it is accepted that the reason is a synergistic effect of extrinsic and intrinsic factors, and the switch in the immune state is an explanation for the development of DLBCL that has received great attention [3-5]. In the normal physiological state, B lymphocytes regulate the humoral immunity, a vital part of the adaptive immune system in the human body. Upon pathogen invasion, specific $\mathrm{T}$ lymphocytes will proliferate or differentiate to effector or memory T cells. Helper T cells (i.e., $\mathrm{CD}^{+}{ }^{+} \mathrm{T}$ cells) then activate specific $B$ cells to produce antibodies for the inhibition or elimination of pathogens. Thus, $\mathrm{CD} 4^{+} \mathrm{T}$ cells play a central role in immune protection by promoting $\mathrm{B}$ cell secretion of antibodies. Unfortunately, the function of Blymphocytes is seriously deficient in DLBCL patients, which leads to abnormal humoral immune response [6-8]; similarly, the cellular immunity is extremely impaired [5,9-13].

A previous study identified two subsets of $\mathrm{CD}^{+} \mathrm{T}$ lymphocytes based on cytokine production and function [14]. To date, it was found that naive $C D 4^{+} \mathrm{T}$ helper cell (Th) precursors can differentiate into functionally distinct $\mathrm{T}$ cell lineages at least including Th1, Th2, Th17, and $\mathrm{T}$ regulatory (Treg) cells upon activation [15]. Among the critical signals that direct the induced patterns of gene expression in maturing helper $\mathrm{T}$ cell subsets are cytokineinduced specific transcription factors. IL-12 drives Th1 cell differentiation through the activation of the transcription factors STAT4 and T-bet [16,17], and Th1 cells mainly secrete several cytokines, such as IL-2 and IFN- $\gamma$ to meditate cellular immunity. IL-4 induces Th2 cell differentiation through the actions of STAT6 and GATA-3 [18], and Th2 cells can produce the immunological factors (such as IL-4 and IL-10) to stimulate B-cell proliferation and antibody production. Whereas Th17 cells differ from Th1 and Th2 cells, whose development is prompted by a combination of IL- 6 plus TGF- $\beta$ and requires expression of STAT3 and the RARrelated orphan receptor gamma $\mathrm{t}$ (ROR $\mathrm{t}$ ) [19], and mainly meditate inflammatory reactions, autoimmune diseases, and transplantation rejections, and are closely related to Treg cells. Treg cells negatively regulate immune function in the anti-inflammatory reaction and maintenance of immune tolerance by secreting cytokines (e.g., IL10 and TGF- $\beta$ ). TGF- $\beta$ is a pleiotropic cytokine, involved in many different critical processes, such as embryonal development, cellular maturation and differentiation, wound healing, and immune regulation. Paradoxically, in cancer, TGF- $\beta$ has been demonstrated to be a potent inhibitor of cell proliferation and acts as a tumor suppressor at the beginning of tumorogenesis. However, once the cells become resistant to TGF- $\beta$, it mainly supports tumor growth and metastasis by promoting immune evasion and angiogenesis [20]. The number and function of these cell types are essential to maintain the balance of the immune system in vivo, especially, in the cross regulation and interrestraint between Th1 and Th2 cells, which can be indirectly detected by analysis of the characteristic cytokines [15]. For example, IFN- $\gamma$ and IL-4 are representative and important stimulating factors that induce differentiation of Th1 and Th2 cells, respectively, and consequently indicate the dynamic equilibrium between Th1 and Th2 cells. Furthermore, T-bet and GATA-3 are important transcription factors in regulating Thl/Th2 cell differentiation. T-bet over-expression induces differentiation into the Th1 lineage, whereas loss of T-bet expression induces the cells' default commitment to Th2 and Th17 lineages, resulting in impaired Th1 immunity. In contrast, knockdown of GATA-3 expression prevents the cells from differentiating into the Th2 lineage and over-expression in Th1 cells switches their polarity to a Th2 phenotype [21,22]. EGR-1 is a multifunctional nuclear transcriptional factor that belongs to a family of early response genes. It induced by pre-TCR signaling has been found to be important in regulation of the early stages of T-lymphocyte development, especially for the $\mathrm{CD} 4^{-} \mathrm{CD} 8^{-}$double negative (DP) to the $\mathrm{CD} 4^{+} \mathrm{CD} 8^{+}$double positive (DP) transition [23]; in addition, recent studies have also described EGR-1 as a tumor repressor that directly or indirectly upregulates multiple tumor suppressors, including PTEN, TP53, fibronectin, BCL-2, and TGF- $\beta 1$, to inhibit cell growth, proliferation, and metastasis, as well as induce apoptosis [24,25]. Nevertheless, during B-lymphocyte tumorigenesis, the distribution of these $\mathrm{T}$ cells and the expression of corresponding regulatory genes could be altered [26], and detection of such alterations and gene expression patterns could be useful in monitoring DLBCL progression and treatment responses.

In our previous studies, we showed that antitumor Tcell clones exist in peripheral blood of DLBCL patients, but they do not possess effective antitumor activity $[11,12]$, which may be due to T-cell anergy, an imbalance of T-cell subsets, or suppression of the immune system. However, little is known about the distribution of T-lymphocyte subpopulations and the expression patterns of different genes in DLBCL patients before and after chemotherapy. In the present study, we aimed to investigate the changes in T-lymphocyte subpopulations and modulation of corresponding cytokines and transcription factors (such as TGF- $\beta$, EGR-1, GATA-3, and T-bet) in PBMCs from DLBCL patients after chemotherapy. 


\section{Results \\ Redistribution of lymphocyte subsets in PBMCs from DLBCL patients}

The percentage of $\mathrm{CD}^{+} \mathrm{T}$ lymphocytes did not differ between healthy controls $(72.90 \pm 5.83 \%)$ and DLBCL patients at baseline $(72.09 \pm 3.16 \%$; p >0.05) or after three cycles of chemotherapy $(71.24 \pm 6.2 \%$; p > 0.05). However, the percentage of $\mathrm{CD}^{+} \mathrm{CD} 4^{+} \mathrm{T}$ cells was significantly decreased $(\mathrm{p}=0.023)$, and the percentages of $\mathrm{CD}^{+} \mathrm{CD}^{+}$and $\mathrm{CD} 4{ }^{+} \mathrm{CD} 25^{+} \mathrm{T}$ lymphocytes $(\mathrm{p}=0.012$ and $\mathrm{p}=0.002$, respectively) were all significantly increased in DLBCL patients at baseline compared to the healthy controls, resulting in a severe inversion of the CD4/CD8 ratio (Table 1). Moreover, after three cycles of chemotherapy, the percentage of $\mathrm{CD} 3^{+} \mathrm{CD} 8^{+} \mathrm{T}$ lymphocytes was significantly decreased $(\mathrm{p}=0.015)$, whereas the percentages of $\mathrm{CD}^{+} \mathrm{CD} 4^{+}$ and $\mathrm{CD} 4{ }^{+} \mathrm{CD} 25^{+} \mathrm{T}$ lymphocytes were increased $(\mathrm{p}=0.095$ and $\mathrm{p}=0.009$, respectively) compared to those at baseline (Table 1). The percentages of $\mathrm{CD}^{+} \mathrm{CD}^{+} \mathrm{T}$ lymphocyte at baseline or after three cycles of chemotherapy in stage III and IV disease were lower than those in stage I and II disease, and the percentage of $\mathrm{CD}^{+} \mathrm{CD}^{+}$and $\mathrm{CD} 4{ }^{+} \mathrm{CD} 25^{+} \mathrm{T}$ lymphocytes at baseline or after three cycles of chemotherapy in stage III and IV disease were higher than those in stage I and II disease, yet there were no statistical significance between two groups (every p > 0.05).

\section{Identification of PCR amplification fragments}

The amplification efficiency for EGR-1, T-bet, GATA-3, and TGF- $\beta$ mRNA was consistent with that of the reference gene GAPDH. All of these transcripts were detected in all of the PBMC samples from the healthy controls and DLBCL patients. The peaks of the melting curves of PCR products for GAPDH mRNA occurred at $84^{\circ} \mathrm{C}$. The peaks of the melting curves for T-bet, GATA3 , EGR-1, and TGF- $\beta$ mRNA were at $86^{\circ} \mathrm{C}, 79^{\circ} \mathrm{C}, 85^{\circ} \mathrm{C}$, and $89^{\circ} \mathrm{C}$, respectively (Figure 1). All PCR products were confirmed using $2 \%$ agarose gel electrophoresis (Figure 2), and the results showed that the amplified fragments of T-bet, GATA-3, EGR-1, TGF- $\beta$, and GAPDH were 159, 204, 160, 203, and $207 \mathrm{bp}$, respectively, and were consistent with the expected sizes.
Altered levels of EGR-1, T-bet, GATA-3, and TGF- $\beta$ mRNA in PBMCs from DLBCL patients at baseline

The levels of EGR-1, T-bet, and GATA-3 mRNA in PBMCs from DLBCL patients at baseline were significantly lower than those from the healthy controls ( $\mathrm{p}<$ 0.05; Figure 3). Specifically, the EGR-1 mRNA level was decreased by 2.69 -fold $( \pm 1.48)$, the T-bet mRNA level was decreased by 9.43 -fold $( \pm 2.14)$, and the GATA-3 mRNA level was decreased by 20.83 -fold $( \pm 9.05)$. Furthermore, there was a positive association between the levels of EGR-1 and T-bet mRNA in PBMCs from patients before chemotherapy $(r=0.84, p=0.001$; Figure 4$)$. However, the level of TGF- $\beta$ mRNA was higher by 2.01 -fold $( \pm 0.51)$ in baseline PBMCs from DLBCL patients than that in the healthy controls. Furthermore, the levels of T-bet and GATA-3 mRNA in stage III and IV disease were lower than those in stage I and II disease, although there was no statistical significance ( $p>0.05)$. The levels of EGR$1 \mathrm{mRNA}$ in stage III and IV disease were significantly lower than those in stage I and II disease (Table 2). In contrast, the level of TGF- $\beta$ mRNA was higher in stage III and IV patients than those in stage I and II patients, yet there was no significant difference between two groups (Table 2). Moreover, an inverse association occurred between the levels of T-bet and TGF- $\beta$ mRNA ( $r=-0.69$, $\mathrm{p}=0.008$; Figure 5). There was no statistical association between the levels of GATA-3 and TGF- $\beta$ mRNA. In addition, the level of TGF- $\beta$ mRNA was positively associated with the percentage of Treg lymphocytes in peripheral blood $(r=0.39, \mathrm{p}=0.011$; Figure 6).

\section{Differential expression of serum IFN- $\gamma$ and IL-4 levels in DLBCL patients at baseline}

Compared to healthy controls, serum levels of IFN- $\gamma$ $(19.7 \pm 10.5 \mathrm{pg} / \mathrm{mL})$ and IL-4 $(1.2 \pm 1.4 \mathrm{pg} / \mathrm{mL})$ in DLBCL patients were significantly lower at baseline $(\mathrm{p}=0.000$ and $\mathrm{p}=0.001$; Figure 7). Moreover, there was a positive association between serum IFN- $\gamma$ level and T-bet mRNA level in PBMCs ( $r=0.64, p=0.018$; Figure 8). The same was true between serum IL-4 level and GATA3 mRNA level in PBMCs $(r=0.71, p=0.005$; Figure 8). Although the serum levels of IFN- $\gamma$ and IL-4 at baseline in stage III and IV patients were lower than those in stage I and II patients, there were no statistical significance between two groups (every p >0.05).

Table 1 Distribution of T-lymphocyte subsets (mean \pm SE) in DLBCL patients at baseline and after three cycles of chemotherapy

\begin{tabular}{|c|c|c|c|c|c|c|}
\hline Group & $\mathbf{N}$ & $\begin{array}{l}\mathrm{CD3}^{+} \mathrm{T} \\
\text { cells (\%) }\end{array}$ & $\begin{array}{l}\mathrm{CD}^{+} \mathrm{CD}^{+} \mathrm{T} \\
\text { cells }(\%)\end{array}$ & $\begin{array}{l}\mathrm{CD}^{+} \mathrm{CD8}^{+} \mathrm{T} \\
\text { cells }(\%)\end{array}$ & $\begin{array}{l}\text { Ratio of } \\
\mathrm{CD}^{+} / \mathrm{CD}^{+}\end{array}$ & $\begin{array}{l}\mathrm{CD}^{+} / \mathrm{CD} 25^{+} \mathrm{T} \\
\text { cells }(\%)\end{array}$ \\
\hline DLBCL patients at baseline & 56 & $72.09 \pm 3.16$ & $32.31 \pm 3.65$ & $37.53 \pm 6.46$ & $0.85 \pm 0.49$ & $5.48 \pm 4.96$ \\
\hline DLBCL after three cycles of chemotherapy & 56 & $71.24 \pm 6.2$ & $34.09 \pm 4.63$ & $32.51 \pm 5.25$ & $1.06 \pm 0.87$ & $8.32 \pm 3.54$ \\
\hline Healthy controls & 26 & $72.90 \pm 5.83$ & $41.78 \pm 4.23$ & $28.51 \pm 2.14$ & $1.47 \pm 0.27$ & $3.68 \pm 1.03$ \\
\hline
\end{tabular}




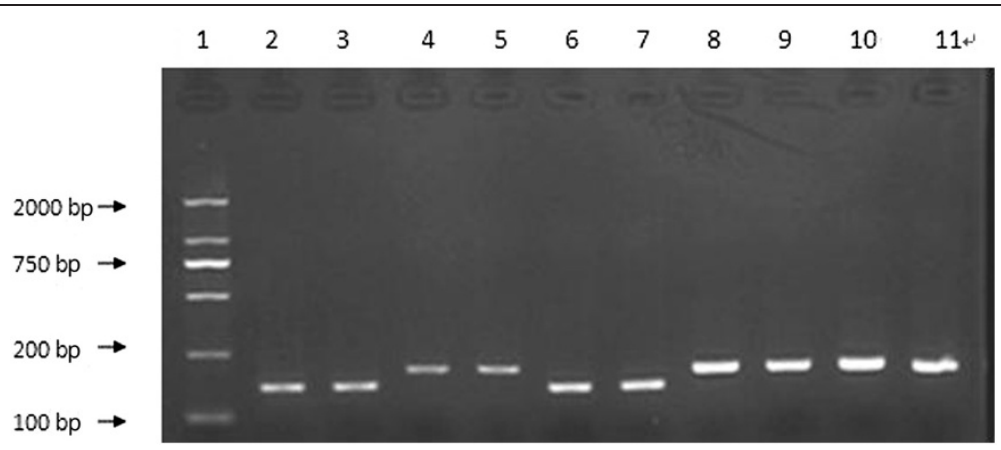

Figure 1 Electrophoresis of PCR-amplified fragments. The fragment lengths of amplification products were 159, 204, 160, 203, and 207 bp. 1, 100-bp marker; 2 and 3: T-bet; 4 and 5: GATA-3; 6 and 7: EGR-1; 8 and 9: TGF- $\beta ; 10$ and 11: GAPDH.

Changes of EGR-1, T-bet, GATA-3, and TGF- $\beta$ mRNA levels in PBMCs from DLBCL patients after chemotherapy

After three cycles of chemotherapy, 36 DLBCL patients experienced complete remission (CR), whereas 20 DLBCL patients achieved partial remission (PR). The levels of EGR-1, T-bet, and GATA-3 mRNA were significantly higher than those before chemotherapy by 6.17 -fold ( \pm 1.43$)$, 4.84-fold $( \pm 0.95)$, and 3.61-fold $( \pm 1.06)$, respectively ( $<<0.05$; Table 3 ). EGR-1 mRNA level was the most significantly increased, reached $2.5( \pm 0.65)$ folds compared to that of healthy controls. The increase in the T-bet mRNA level was apparently higher than that in the GATA-3 mRNA level ( $p=0.002)$. However, the levels of the two transcription factors were still lower by 1.98 -fold $( \pm 1.10)$ and 5.71 -fold $( \pm 1.62)$, respectively, than those in healthy controls. The levels of GATA-3, T-bet, and EGR-1 mRNA were significantly higher in CR patients than those in $P R$ patients $(\mathrm{p}=0.025, \mathrm{p}=0.005$, and $\mathrm{p}=0.002$, respectively; Figure 9). However, the level of TGF- $\beta$ mRNA was still higher than that in healthy controls by 1.24-fold $( \pm 0.57)$, although the chemotherapy reduced the TGF- $\beta$ mRNA level by 1.6 -fold $( \pm 1.04)$. In addition, the TGF- $\beta$ mRNA level was lower in CR patients than in $\mathrm{PR}$ patients $(\mathrm{p}=0.013$; Figure 8).

\section{Discussion}

Accumulating research findings led to the conclusion/ suggestion that there are multiple antitumor T-cell clones in the peripheral blood of DLBCL patients, but these $\mathrm{T}$ lymphocytes fail to retain effective antitumor properties [11,12]. The reason remains to be determined, but it may be due to the T-cell immune anergy and tumor immune escape resulting from imbalance of $\mathrm{T}$ lymphocyte subsets. Indeed, our previous study showed that imbalance T-lymphocyte subsets occurs in PBMCs of DLBCL patients during different chemotherapy stages, and these T-lymphocyte subsets gradually return to normal by 3 months after chemotherapy [27]. CD4 ${ }^{+} \mathrm{T}$

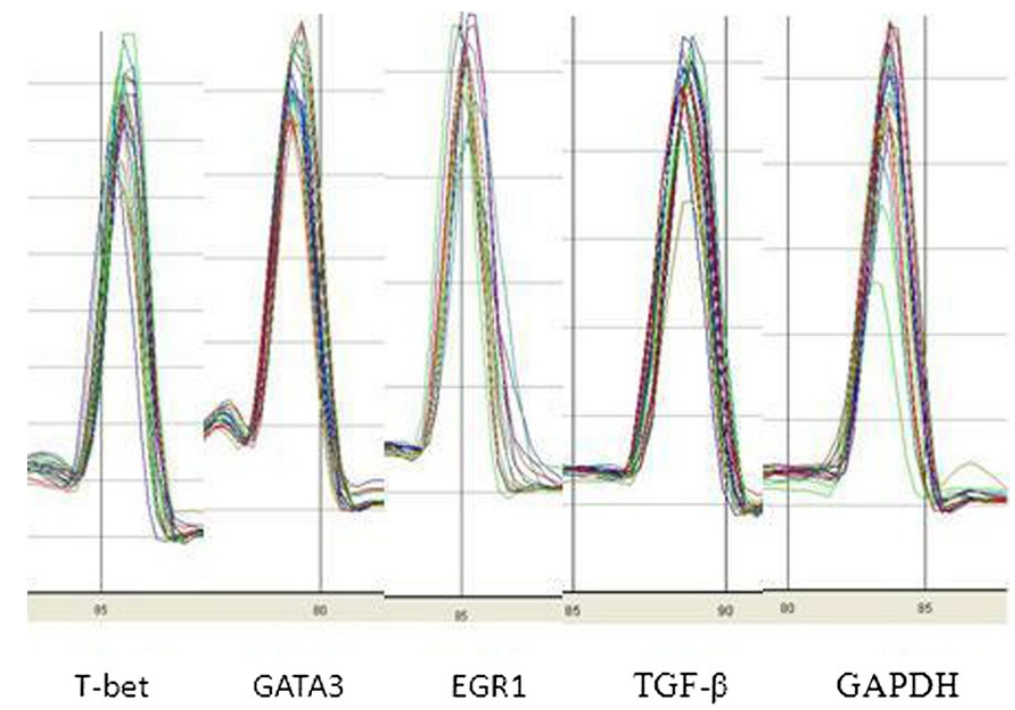

Figure 2 qPCR detection of the peaks of melting curves for each transcript. The peaks of the melting curves of PCR products for T-bet, GATA-3, EGR-1, TGF- $\beta$, and GAPDH reference gene were at $84^{\circ} \mathrm{C}, 86^{\circ} \mathrm{C}, 79^{\circ} \mathrm{C}, 85^{\circ} \mathrm{C}$, and $89^{\circ} \mathrm{C}$, respectively. 


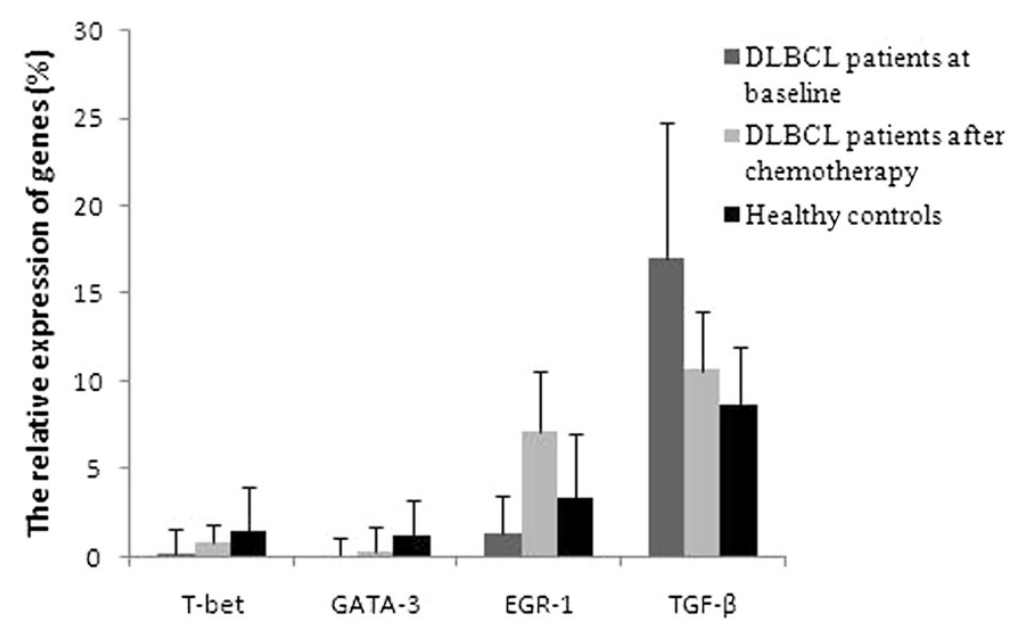

Figure 3 Relative expression levels of EGR-1, T-bet, GATA-3, and TGF- $\beta$ mRNA in DLBCL patients before and after three cycles of chemotherapy. Gene expression was detected using qRT-PCR.

cells are critical in the specific and nonspecific immune response. Under normal circumstances, immature $\mathrm{CD}^{+} \mathrm{T}$ (Th0) cells differentiate into certain mature subtype for specific immune response by antigen and cytokine stimulation. Both IFN- $\gamma$ and IL-4, representative cytokines secreted by Th1 and Th2 cells, are main factors that stimulate and induce Th0 cell differentiation into Th1/Th2 cells. In the current study, we found that the percentage of $\mathrm{CD} 4^{+} \mathrm{T}$ cells was strikingly decreased in PBMCs from DLBCL patients, whereas the percentage of Treg cells was unusually high, resulting in few cytokines secreted by Th1 and Th2 cells, the imbalance of which could always be assessed by the expression levels of these two cytokines [28].

Furthermore, both T-bet and GATA-3 are key transcription factors in regulating Th1/Th2 cell differentiation; thus, their expression directly affects the dynamic balance of the Th1/Th2 subpopulations. A previous study demonstrated that decreased T-bet expression and increased GATA-3 expression occurred in PBMCs of patients with different solid tumors [29], whereas increased T-bet expression and decreased GATA-3 expression were found in aplastic anemia patients [30]. However, to date, their expression levels are unknown in PBMCs from DLBCL patients. Our current data revealed that the levels of these two transcription factors were significantly lower in DLBCL patients than those in healthy controls, suggesting that there were few Th1 and Th2 cells in the peripheral blood of DLBCL patients. Their expression levels were even lower in DLBCL patients with stage III or IV disease than in those with stage I or II disease, which also suggests that patients with disseminated lesions have further

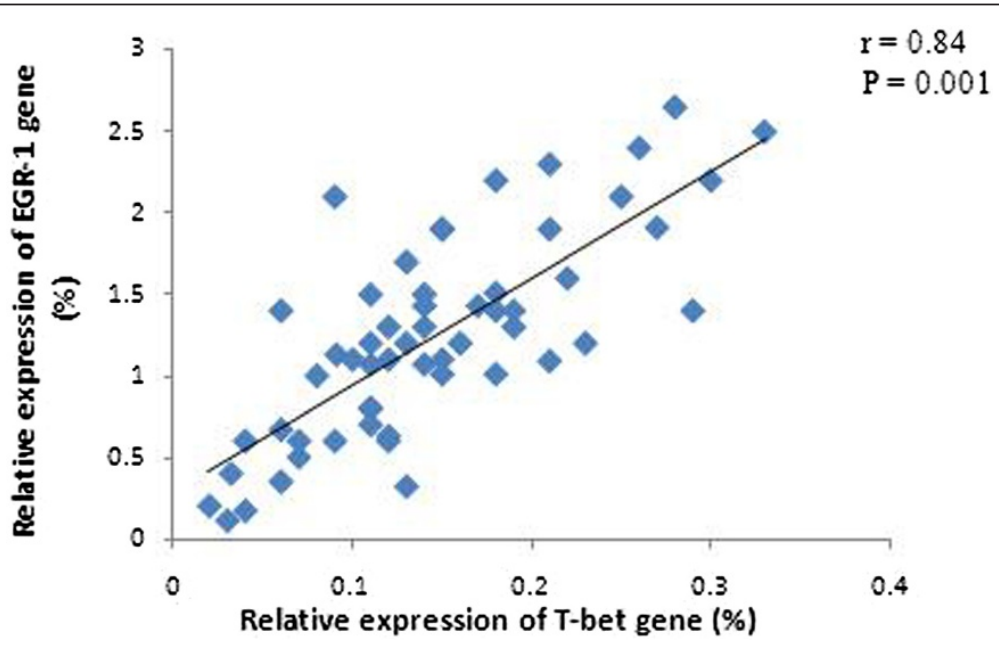

Figure 4 Association of the relative expression levels of EGR-1 and T-bet genes in PBMCs from DLBCL patients at baseline. There was an obvious positive association between the expression levels of EGR-1 and T-bet mRNA. Gene expression was detected using qRT-PCR. 
Table 2 Differential gene expression between DLBCL patients with different disease stages at baseline

\begin{tabular}{|c|c|c|c|c|c|c|c|c|}
\hline & \multicolumn{2}{|l|}{ EGR-1 } & \multicolumn{2}{|l|}{ T-bet } & \multicolumn{2}{|l|}{ GATA-3 } & \multicolumn{2}{|l|}{ TGF- $\beta$} \\
\hline & $\overline{\Delta \Delta \mathrm{Ct}^{1}}$ & $2^{-\Delta \Delta C t 1}$ & $\overline{\Delta \Delta \mathrm{Ct}^{1}}$ & $2^{-\Delta \Delta C t 1}$ & $\overline{\Delta \Delta \mathrm{Ct}^{1}}$ & $2^{-\Delta \Delta \mathrm{Ct} 1}$ & $\overline{\Delta \Delta \mathrm{Ct}^{2}}$ & $2^{-\Delta \Delta C \mathrm{t} 2}$ \\
\hline Stage I-II & $-0.120 \pm 0.67$ & $1.09 \pm 0.23$ & $-2.496 \pm 0.568$ & $5.65 \pm 1.05$ & $-3.742 \pm 0.714$ & $13.33 \pm 2.65$ & $0.723 \pm 0.793$ & $0.605 \pm 0.51$ \\
\hline Stage III-IV & $-2.952 \pm 0.851$ & $7.69 \pm 2.10$ & $-4.099 \pm 1.272$ & $17.24 \pm 4.23$ & $-5.143 \pm 1.632$ & $35.71 \pm 12.41$ & $1.337 \pm 0.931$ & $0.395 \pm 0.46$ \\
\hline$P$ & $0.008^{*}$ & & 0.068 & & 0.144 & & 0.092 & \\
\hline
\end{tabular}

Note: $\Delta \Delta \mathrm{Ct}^{1}=\Delta \mathrm{Ct}_{\text {target gene in control- }} \Delta \mathrm{Ct}_{\text {target gene in patients, }} 2^{-\Delta \Delta \mathrm{Ct} 1}$ indicates the fold decrease in the expression of target genes in patients compared to controls. $\Delta \Delta \mathrm{Ct}^{2}=\Delta \mathrm{Ct}$ TGF- $\beta$ in patient $-\Delta \mathrm{Ct}$ TGF- $\beta$ in control, $2^{-\Delta \Delta \mathrm{Ct} 2}$ indicates the fold increase in TGF- $\beta$ expression in patients compared to controls. ${ }^{*}$ indicates that there is significant difference between two groups.

decreased immune function and antitumor invasion capacity compared to patients with localized lesions. After three cycles of chemotherapy, the levels of T-bet and GATA-3 mRNA had increased significantly. However, it remains to be further investigated whether the increased levels of T-bet and GATA-3 mRNA contribute to the restoration of Th1 cell immune function.

Effective immune responses against different antigens are dependent on T-cell differentiation. T-bet, one of the specific transcription factors, is vital in all three important differentiation pathways of Th1 cells, i.e., TCR/EGR1, INF- $\gamma /$ STAT-1, and IL-12/STAT-4 signaling pathways. A low level of INF- $\gamma$ is needed for the initial activation of T-bet, which intensely stimulates the Tbx 21 gene and promotes expression of T-bet through the INF- $\gamma /$ STAT1 signaling pathway [31]. Thus, the balance of T-bet and GATA-3 gene expression should be appropriately modulated during treatment, especially in elderly patients with disseminated lesions. IFN- $\gamma$ intervention not only directly inhibits tumor growth but also improves in vivo T-bet expression after chemotherapy to promote the early reconstruction of Th1 cells and enhance antitumor immune responses. Most importantly, the TCR/EGR-1 pathway strikingly induces T-bet expression compared to the other two signaling pathways [32]. Notably, over- expression of EGR-1 through binding of EGR-1 to T-bet promoter transactivates, in concert with TCR signaling, and synergistically induces T-bet expression [33]. In the current study, we found that the level of EGR-1was reduced in DLBCL patients and was even lower in patients with disseminated lesions than that in patients with localized lesions. Interestingly, the level of EGR-1 mRNA was significantly increased by more than 2 -fold in DLBCL patients after three cycles of chemotherapy. Meanwhile, T-bet expression was also apparently increased, and the increased level of T-bet mRNA was significantly higher than that of GATA-3 mRNA, suggesting that EGR-1 was positively associated with T-bet expression.

Indeed, Th1 plays an important role in enhancing the response in cell-mediated immunity. In contrast, the effects of Th2 cells mediate humoral immunity. Thus, these two types of cells are essential in maintaining the balance of the immune system. In the current study, we tried to understand the levels and balance of Th1/Th2 cells in PBMCs from DLBCL patients by analyzing corresponding transcription factors and cytokines in DLBCL patients. Our data showed that the levels of Th1 and Th2 cells were significantly lower in DLBCL patients than that in normal individuals, which will inevitably cause

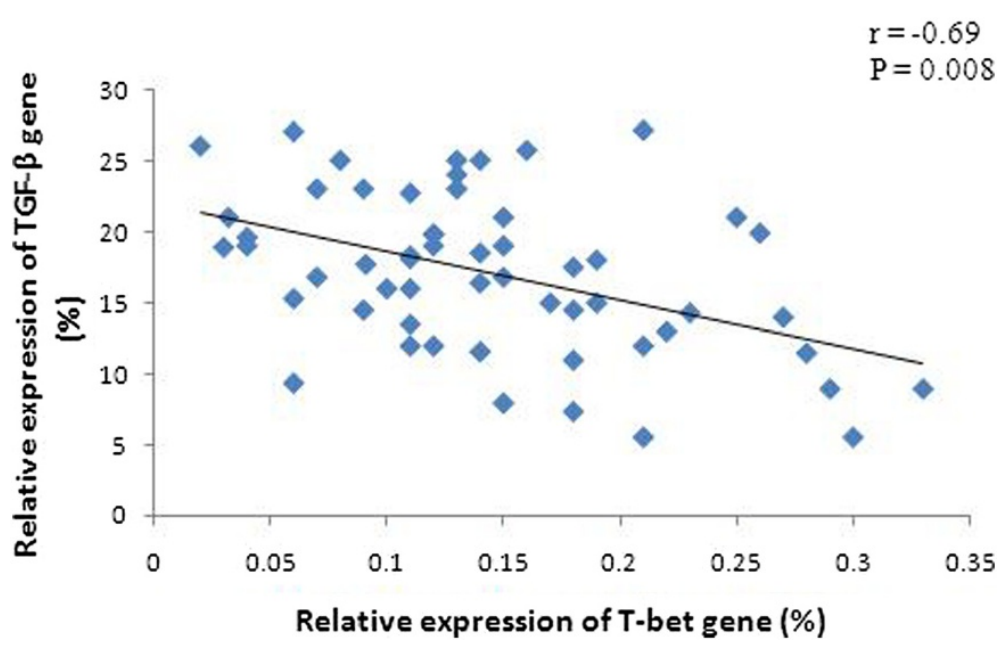

Figure 5 Association of the relative expression levels of TGF- $\beta$ and T-bet genes in PBMCs from DLBCL patients at baseline. There was an obvious negative association between the expression levels of TGF- $\beta$ and T-bet mRNA. Gene expression was detected using qRT-PCR. 


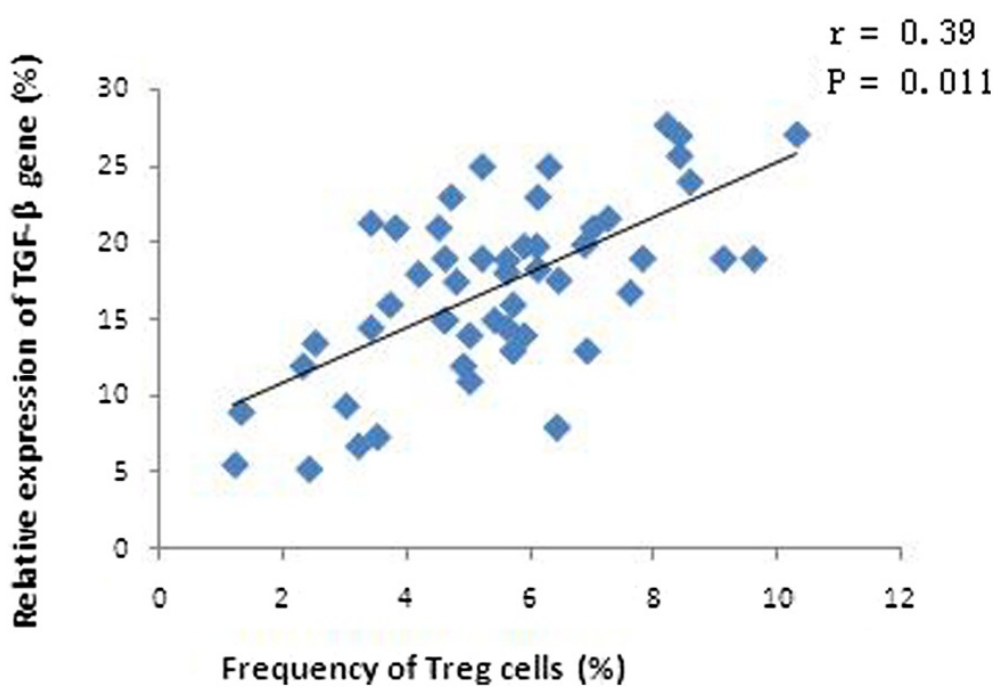

Figure 6 Association of the relative expression levels of TGF- $\beta$ genes and the percentage of Treg cells in peripheral blood from DLBCL patients at baseline. There was an obvious positive association between the expression levels of TGF- $\beta$ and the percentage of Treg cells. Gene expression was detected using qRT-PCR, and Treg cells were sorted by flow cytometry.

deficiencies in cellular and humoral immune function in DLBCL patients. In addition, tolerance induction in $\mathrm{T}$ cells takes place in most tumors and is thought to account for tumor evasion from immune eradication. Increased expression of cytokine TGF- $\beta$ from tumor cells and $\mathrm{T}$ cells is associated with the occurrence, development, and prognosis of tumors by promoting tumor progression and inhibiting the immune response and surveillance system in vivo [34-37]. Our current study demonstrated that over-expression of TGF- $\beta$ mRNA in PBMCs from patients at baseline was positively associated with a higher percentage of Treg cells, the increase of which was related to the patient's immune tolerance and tumor immune escape. The level of TGF- $\beta$ mRNA was reduced significantly after chemotherapy, but was still higher than that in healthy controls. TGF- $\beta$ inhibition of the immune system is activated mainly through the ERK-2 pathway to affect expression of multiple transcription factors (e.g., T-bet and GATA-3), which seriously hampers Th1 and Th2 cell differentiation and promotes the generation of Foxp3(+) Treg cells [38,39], consistently with our current findings.

In summary, the current results demonstrate, for the first time, the changes of distribution of Th1/Th2 cells and the altered expression pattern of the corresponding regulatory genes in PBMCs from DLBCL patients after chemotherapy, which are associated with the response of patients to treatment. The preferential expression of the T-bet gene after chemotherapy was closely correlated with the increased expression of the EGR1 gene and decreased expression of the TGF- $\beta$ gene. Thus, the data from the current study demonstrate that immune regulation therapy may be useful as adjuvant treatment in DLBCL patients in the future.
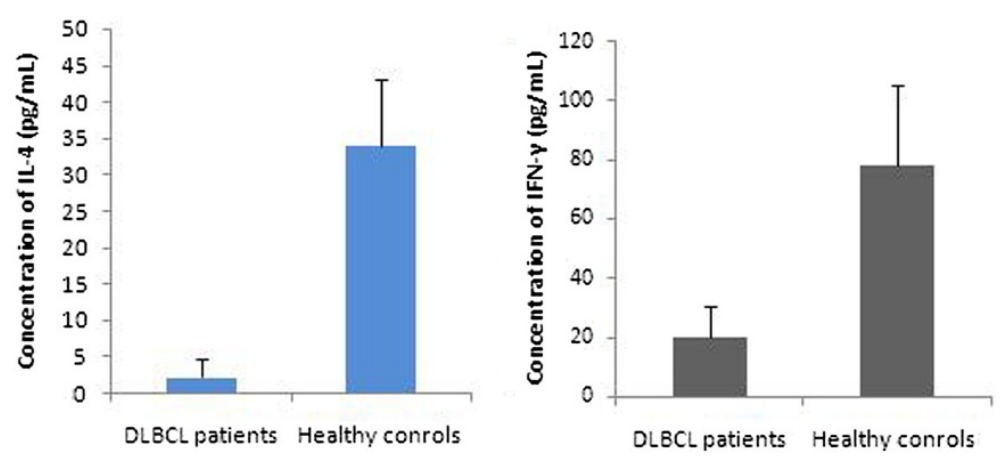

Figure 7 Serum levels of IFN- $\gamma$ and IL-4 proteins in DLBCL patients at baseline. Compared to those in the healthy controls, serum levels of IFN- $\gamma$ and IL-4 were significantly lower in DLBCL patients at baseline. Serum levels of IL-4 and IFN- $\gamma$ proteins were detected by ELISA. 

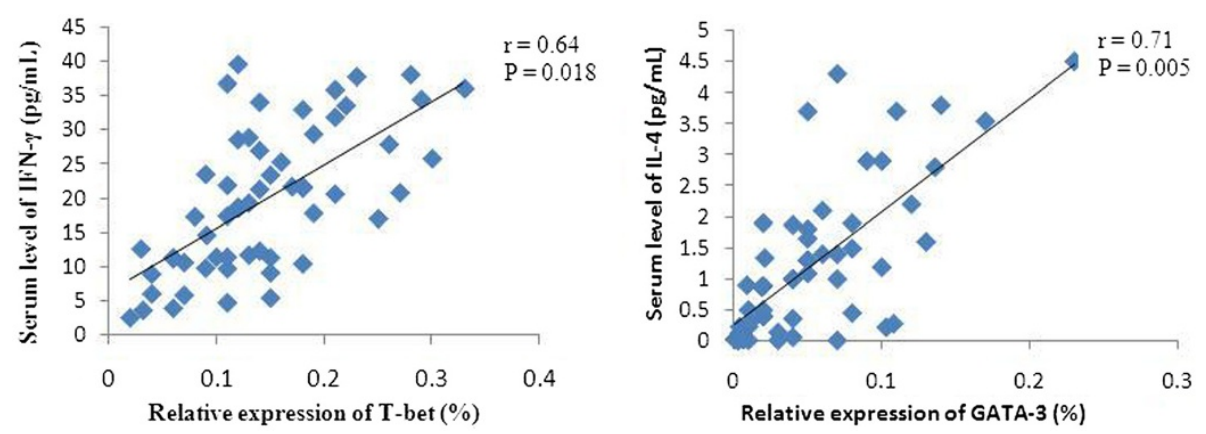

Figure 8 Association of serum IFN- $\gamma /$ IL-4 levels at baseline and the relative expression levels of T-bet/GATA-3 genes. There was a positive association between serum IFN- $\gamma$ level and T-bet mRNA level, yet between serum IL-4 level and GATA3 mRNA level in PBMCs. Serum IL-4 and IFN- $\gamma$ levels were detected by ELISA, and gene expression was detected using qRT-PCR.

\section{Patients and methods}

\section{Study population}

A total of 56 patients (26 females and 30 males, median age 48 years, range from 24 to 72 years) were recruited from the Affiliated Cancer Hospital of Zhengzhou University between March 2009 and April 2013. These patients were newly diagnosed with DLBCL based on routinely accepted clinical and laboratory criteria with histological/cytological confirmation. According to the Ann Arbor standard staging criteria, all the patients were staged by color Doppler ultrasound, computed tomography, bone marrow biopsy, and serum lactate dehydrogenase levels. None of these 56 patients showed any bone marrow involvement. Clinically, 27 patients were at stage I to II, and 29 were at stage III to IV. Nineteen patients were older than 60 years old (i.e., 9 at stage II and 10 at stage III). All patients received CHOP (25 patients), CHOP-B (12 patients), or R-CHOP (19 patients) chemotherapy regimens. CHOP chemotherapy was administered as follows: one course of chemotherapy consisting of an intravenous infusion of $750 \mathrm{mg} / \mathrm{m}^{2}$ cyclophosphamide, $50 \mathrm{mg} / \mathrm{m}^{2}$ adriamycin, $2 \mathrm{mg}$ vincristine, and an oral administration of $100 \mathrm{mg}$ prednisone on days 1 to 5 , which was repeated every 3 weeks. For the R-CHOP regimen, $375 \mathrm{mg} / \mathrm{m}^{2}$ rituximab was infused over 4 to 6 hours on day 1 before CHOP chemotherapy was started. For the CHOP-B regimen, intravenous bleomycin $\left(15 \mathrm{mg} / \mathrm{m}^{2}\right)$ was added on the basis of a standard
CHOP scheme. Treatment efficacy was evaluated after three cycles of chemotherapy. This study was approved by our hospital review board, and each patient signed a consent form for participation in this study.

\section{Collection and analysis of blood samples}

Peripheral blood samples were collected from 56 DLBCL patients and 26 healthy volunteers, and blood was withdrawn twice for the patients (at baseline and before the fourth chemotherapy cycle). The blood samples were immediately processed, and $1 \mathrm{~mL}$ serum from each subject was frozen and stored at $-20^{\circ} \mathrm{C}$ until use. The PBMCs were obtained using the Ficoll-Hypaque gradient centrifugation method within 1 hour after blood sample collection. Samples of $5-10 \times 10^{5}$ PBMCs from each patient at baseline and before the fourth chemotherapy cycle were used for flow cytometric detection of T-lymphocyte subsets, and the remaining cells were stored at $-70^{\circ} \mathrm{C}$ for analysis of cytokines and transcription factors.

\section{Flow cytometric (FCM) detection of T-lymphocyte subsets}

Flow cytometry was used to assess the distributions of $\mathrm{CD}^{+}, \mathrm{CD}_{3}{ }^{+} \mathrm{CD} 4^{+}, \mathrm{CD}^{+} \mathrm{CD}^{+}$, and $\mathrm{CD} 4^{+} \mathrm{CD} 25^{+} \mathrm{CD} 127^{-} \mathrm{T}$ cells in PBMCs from healthy volunteers and patients at baseline and before the fourth cycle of chemotherapy. Monoclonal anti-CD3-PECY5, CD4-FITC, CD8-PE, and CD25-PE antibodies (BD Biosciences, San Diego, CA, USA) were used for the FCM detections according to

Table 3 Differential gene expression in DLBCL patients before and after chemotherapy

\begin{tabular}{|c|c|c|c|c|c|c|c|c|}
\hline & \multicolumn{2}{|l|}{ EGR-1 } & \multicolumn{2}{|l|}{ T-bet } & \multicolumn{2}{|l|}{ GATA-3 } & \multicolumn{2}{|l|}{ TGF- $\beta$} \\
\hline & $\overline{\Delta \Delta C t^{1}}$ & $2^{-\Delta \Delta C t}$ & $\overline{\Delta \Delta \mathrm{Ct}^{1}}$ & $2^{-\Delta \Delta C t}$ & $\overline{\Delta \Delta C t^{1}}$ & $2^{-\Delta \Delta C t}$ & $\overline{\Delta \Delta C \mathrm{t}^{2}}$ & $2^{-\Delta \Delta C t}$ \\
\hline Before chemotherapy & $-1.427 \pm 0.565$ & $2.67 \pm 1.48$ & $-3.236 \pm 1.667$ & $9.43 \pm 2.14$ & $-4.388 \pm 0.839$ & $20.83 \pm 9.05$ & $1.001 \pm 0.943$ & $2.01 \pm 0.51$ \\
\hline After three cycles of chemotherapy & $1.117 \pm 0.644$ & $0.44 \pm 0.23$ & $-0.987 \pm 0.606$ & $1.98 \pm 1.10$ & $-2.517 \pm 0.796$ & $5.71 \pm 1.62$ & $0.314 \pm 0.268$ & $1.24 \pm 0.57$ \\
\hline $\mathrm{p}$ & $0.001^{*}$ & & $0.002^{*}$ & & $0.028^{*}$ & & 0.095 & \\
\hline
\end{tabular}

Note: $\Delta \Delta \mathrm{Ct}^{1}=\Delta \mathrm{Ct}$ target gene in control- $\Delta \mathrm{Ct}$ target gene in patients, $2^{-\Delta \Delta \mathrm{Ct} 1}$ indicates the fold decrease in the expression of target genes in patients compared to controls. $\Delta \Delta \mathrm{Ct}^{2}=\Delta \mathrm{Ct}$ TGF- $\beta$ in patient $-\Delta \mathrm{Ct}$ TGF- $\beta$ in control, $2^{-\Delta \Delta \mathrm{Ct} 2}$ indicates the fold increase in TGF- $\beta$ expression in patients compared to controls. ${ }^{*}$ indicates that there is significant difference between two groups. 


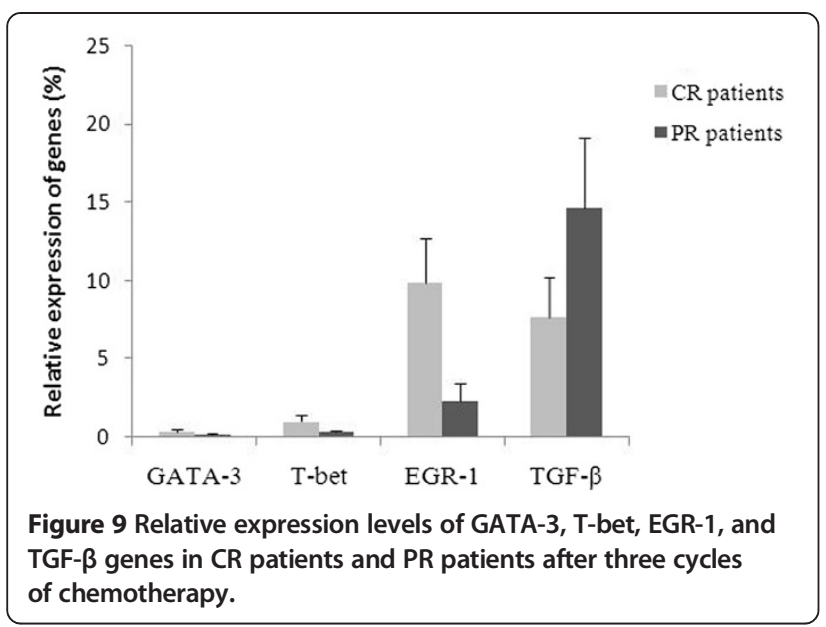

the manufacturer's instructions. The EP-ICS2XL flow cytometer (Beckman Coulter, Brea, CA, USA) was used for acquisition and analysis of FCM data.

\section{ELISA detection of serum IL-4 and IFN- $\gamma$ levels}

Serum levels of IL-4 and IFN- $\gamma$ proteins from DLBCL patients at baseline were assessed using corresponding enzyme-linked immunosorbent assay (ELISA) kits (Takara, Dalian, China) according to the manufacturer's protocols. Briefly, $100 \mu \mathrm{L}$ of serum samples was added to each well of microwell plates previously coated with a polyclonal anti-IL4 or IFN- $\gamma$ antibody, and the plates were incubated for $2 \mathrm{~h}$ at room temperature. After a wash with phosphate-buffered saline (PBS), a polyclonal biotin-conjugated IL-4 or IFN- $\gamma$ antibody was added to each well, and the plates were further incubated for $1 \mathrm{~h}$ at room temperature. After washing, streptavidin-horseradish peroxidase (HRP) was added to each well and incubated for $1 \mathrm{~h}$, and then the unbound streptavidin-HRP was washed away. Next, the color reagent for HRP was added to the wells, and the absorbance was measured at $450 \mathrm{~nm}$ using an Elx808IU Ultra Microplate Reader (Bio-Tek, Winooski, VT, USA). A standard curve was constructed using the IL-4 or IFN- $\gamma$ protein standards provided in the kits. Each sample was analyzed in triplicate.

\section{RNA isolation and qRT-PCR}

Total cellular RNA was isolated from 1-5 $\times 10^{6}$ PBMCs using a Trizol reagent (Invitrogen, Carlsbad, CA, USA) and then $2 \mu \mathrm{g}$ RNA was reversely transcribed into the first single-strand cDNA using random hexamer primers and the Superscript II reverse transcriptase Kit (Invitrogen, USA) according to the manufacturer's instructions. The RNA quality was analyzed in $0.8 \%$ agarose gel stained with ethidium bromide. The cDNA quality was confirmed by RT-PCR for glyceraldehyde-3-phosphate (GAPDH) reference gene amplification.

For the detection of EGR-1, T-bet, GATA-3, TGF- $\beta$, and GAPDH reference gene mRNA levels by SYBR
Table 4 Primer sequences for qPCR

\begin{tabular}{ll}
\hline Gene & Sequences \\
\hline GAPDH & 5'-ACGGATTGGTCGTATTG-3' \\
& 5'-GGAAGATGGTGATGGGATT-3' \\
T-bet & 5'-GGGCGTCCAACAATGTGA-3' \\
& 5'-CGGCAATGAACTGGGTT-3' \\
Gata-3 & 5'-ATGAAGGATGCCAAGAAGT-3' \\
& 5'-TGAACAAATGATTCGCCTA-3' \\
EGR-1 & 5'-CGATGAACGCAAGAGGCA-3 \\
& 5'-CGGGGATGGATAAGAGGTAGT-3' \\
TGF- 3 & 5'-GAAACCCACAACGAAATCT-3' \\
& 5'-AGGTATCGCCAGGAAT-3' \\
\hline
\end{tabular}

Green I real-time PCR (Ex Taq II-DRR820A, Takara), the primers (Table 4) were synthesized by Shanghai SANGON Biological Engineering Technology Services Co., Ltd. (Shanghai, China). PCR amplification was performed using an ABI 7300 (Applied Biosystems, Foster City, CA, USA) in a $25 \mu \mathrm{L}$ total volume containing $50 \mathrm{ng} / \mu \mathrm{L}$ cDNA, $10 \mu \mathrm{mol} / \mathrm{L}$ primer pairs, $10 \mu \mathrm{L}$ of $2 \times$ Real Master Mix (Ex Taq II-DRR820A, Takara), and $0.4 \mu \mathrm{L}$ ROX (Ex Taq II-DRR820A, Takara) with an initial denaturation at $95^{\circ} \mathrm{C}$ for $30 \mathrm{~s}$ and then 40 cycles of $95^{\circ} \mathrm{C}$ for $15 \mathrm{~s}$ and $61^{\circ} \mathrm{C}$ for $31 \mathrm{~s}$. Additionally, a specific amplification of the PCR products was analyzed by melting curve analysis and agarose gel electrophoresis. On the basis of the consistent amplification efficiency for each of target genes and GAPDH reference gene, the relative amount of the target genes was normalized to that of GAPDH mRNA in two independent assays using the $2^{-\Delta \mathrm{Ct}} \times 100 \%$ and $2^{-\Delta \Delta \mathrm{Ct}}$ methods [40-42].

\section{Statistical analysis}

All statistical analyses were performed using the Statistical Package for Social Sciences software (SPSS 18.0, Chicago, IL, USA), and the data are presented as mean \pm standard error (SE). Differences in mRNA levels between the two groups were analyzed using Student's $t$ test. The Spearman's rank correlation analysis was performed to detect differences in the mRNA expression of EGR-1, T-bet, GATA-3, and TGF- $\beta$ in different samples. $\mathrm{P}<0.05$ was considered statistically significant.

\section{Competing interest}

The authors declare that they have competing interest.

\section{Authors' contributions}

XDW and QSY contributed to the concept development and study design. QSY and LC contributed equally to this work. They performed the real-time $P C R$, and participated in the analysis of data, had been involved in drafting and revising the manuscript. QYL and RHM performed ELISA and FCM. YFL and YPS were responsible for the collection of clinical data. All authors read and approved the final manuscript. 


\section{Acknowledgments}

The authors would like to thank the patient for his cooperation. This work has been supported by a grant from the National Natural Science

Foundation of China (grant no.: 81000921).

Received: 13 February 2014 Accepted: 12 August 2014

Published online: 24 December 2014

\section{References}

1. Turner JJ, Morton LM, Linet MS, Clarke CA, Kadin ME, Vajdic CM, Monnereau A, Maynadié M, Chiu BC, Marcos-Gragera R, Costantini AS, Cerhan JR, Weisenburger DD: InterLymph hierarchical classification of lymphoid neoplasms for epidemiologic research based on the WHO classification (2008): update and future directions. Blood 2010, 116(20):e90-e98. doi:10.1182/blood-2010-06-289561.

2. Cunningham D, Hawkes EA, Jack A, Qian W, Smith P, Mouncey P, Pocock C, Ardeshna KM, Radford JA, McMillan A, Davies J, Turner D, Kruger A, Johnson P, Gambell J, Linch D: Rituximab plus cyclophosphamide, doxorubicin, vincristine, and prednisolone in patients with newly diagnosed diffuse large B-cell non-Hodgkin lymphoma: a phase 3 comparison of dose intensification with 14-day versus 21-day cycles. Lancet 2013, 381(9880):1817-1826. doi:10.1016/50140-6736(13)60313-X.

3. Simard JF, Baecklund F, Chang ET, Baecklund E, Hjalgrim $H_{\text {, }}$-OlovAdami $H_{\text {, }}$ Glimelius B, Smedby KE: Lifestyle factors, autoimmune disease and family history in prognosis of non-hodgkin lymphoma overall and subtypes. Int J Cancer 2013, 132(11):2659-2666. doi:10.1002/ijc.27944.

4. Grulich AE, Vajdic CM, Cozen W: Altered immunity as a risk factor for non-Hodgkin lymphoma. Cancer Epidemiol Biomarkers Prev 2007, 16(3):405-408

5. Li YQ: T-cell immunodeficiency and reconstruction based on TCR rearrangement analysis in hematological malignancy: update from 2011 ASH annual meeting. J Hematol Oncol 2012, 5(Suppl 1):A3. doi:10.1186/ 1756-8722-5-S1-A3.

6. Komeno Y, Kitaura J, Watanabe-Okochi N, Kato N, Oki T, Nakahara F, Harada Y, Harada H, Shinkura R, Nagaoka H, Hayashi Y, Honjo T, Kitamura T: AID-induced T-lymphoma or B-leukemia/lymphoma in a mouse BMT model. Leukemia 2010, 24(5):1018-1024. doi:10.1038/leu.2010.40.

7. Park SR: Activation-induced cytidine deaminase in B cell immunity and cancers. Immune Netw 2012, 12(6):230-239. doi:10.4110/in.2012.12.6.230.

8. Inaoka RJ, Jungbluth AA, Gnjatic S, Ritter E, Hanson NC, Frosina D, Tassello J, Etto LY, Bortoluzzo AB, Alves AC, Colleoni GW: Cancer/testis antigens expression and autologous serological response in a set of Brazilian non-Hodgkin's lymphoma patients. Cancer Immunol Immunother 2012, 61(12):2207-2214. doi:10.1007/s00262-012-1285-6.

9. Afshar-Sterle S, Zotos D, Bernard NJ, Scherger AK, Rödling L, Alsop AE, Walker J, Masson F, Belz GT, Corcoran LM, O'Reilly LA, Strasser A, Smyth MJ, Johnstone R, Tarlinton DM, Nutt SL, Kallies A: Fas ligand-mediated immune surveillance by $T$ cells is essential for the control of spontaneous $B$ cell lymphomas. Nat Med 2014, 20(3):283-290. doi:10.1038/nm.3442.

10. Danielou-Lazareth A, Henry G, Geromin D, Khaznadar Z, Briere J, Tamouza R, Cayuela JM, Thieblemont C, Toubert A, Dulphy N: At diagnosis, diffuse large B-cell lymphoma patients show impaired rituximab-mediated NK-cell cytotoxicity. Eur J Immunol 2013, 43(5):1383-1388. doi:10.1002/eji.201242733.

11. Yin QS, Yang LJ, Chen SH, Zhou YB, Wu XL, Li YQ: Generation of diffuse large B cell lymphoma-associated antigen-specific Valpha6/Vbeta13 + T cells by TCR gene transfer. J Hematol Oncol 2011, 4:2. doi:10.1186/ 1756-8722-4-2.

12. Yin QS, Tan $H$, Chen S, Yang L, Ye JM, Li YQ: Charaterization of conserved CDR3 sequence of TCR $\alpha$ - and $\beta$-chain genes in peripheral blood T-cells from patients with diffuse large B-cell lymphoma. Hematology 2010, 15(1):48-57. doi:10.1179/ 102453310X12583 347009694

13. Yin QS, Wei XD, Wang XJ, Mi RH, Lv XD, Wang Q, Zhao HF, Li YF, Song YP: Clinical significence of dynamic monitoring of thymic recent output function in different stages of treatment in patients with diffuse large B-cell lymphoma. Chin J Hematol 2013, 32(1):55-59.

14. Mosmann TR, Cherwinski H, Bond MW, Giedlin MA, Coffman RL: Two types of murine helper T cell clone. I. Definition according to profiles of lymphokine activities and secreted proteins. 1986. J Immunol 2005, 175(1):5-14.
15. Zhu JF, Paul WE: CD4 T cells: fates, functions, and faults. Blood 2008, 112(5):1557-1569.

16. Szabo SJ, Kim ST, Costa GL, Zhang X, Fathman CG, Glimcher LH: A novel transcription factor, T-bet, directs Th1 lineage commitment. Cell 2000, 100(6):655-669.

17. Szabo SJ, Sullivan BM, Peng SL, Glimcher LH: Molecular mechanisms regulating Th1 immune responses. Annu Rev Immunol 2003, 21:713-758.

18. Kaplan MH, Schindler U, Smiley ST, Grusby MJ: Stat6 is required for mediating responses to IL-4 and for development of Th2 cells. Immunity 1996, 4(3):313-319.

19. Ivanov II, McKenzie BS, Zhou L, Tadokoro CE, Lepelley A, Lafaille JJ, Cua DJ, Littman DR: The orphan nuclear receptor RORgammat directs the differentiation program of proinflammatory IL-17+ T helper cells. Cell 2006, 126(6):1121-1133.

20. Mantel PY, Schmidt-Weber CB: Transforming growth factor-beta: recent advances on its role in immune tolerance. Methods Mol Biol 2011, 677:303-338. doi:10.1007/978-1-60761-869-0_21.

21. Oestreich KJ, Weinmann AS: Transcriptional mechanisms that regulate T helper 1 cell differentiation. Curr Opin Immunol 2012, 24(2):191-195. doi:10.1016/j.coi.2011.12.004.

22. Pai SY, Kang BY, Sabadini AM, Parisini E, Truitt ML, Ho IC: Distinct structural requirements of GATA-3 for the regulation of thymocyte and Th2 cell differentiation. J Immunol 2008, 180(2):1050-1059.

23. Carleton M, Haks MC, Smeele SA, Jones A, Belkowski SM, Berger MA, Linsley $P$, Kruisbeek AM, Wiest DL: Early growth response transcription factors are required for development of $\mathrm{CD} 4{ }^{-} \mathrm{CD} 8^{-}$thymocytes to the $\mathrm{CD} 4^{+} \mathrm{CD} 8^{+}$ stage. J Immunol 2002, 168(4):1649-1658.

24. Boone DN, Qi Y, Li Z, Hann SR: Egr1 mediates p53-independent c-Myc-induced apoptosis via a noncanonical ARF-dependent transcriptional mechanism. Proc Natl Acad Sci U S A 2011, 108(2):632-637. doi:10.1073/pnas.1008848108

25. Zhang HH, Chen XJ, Wang JK, Guang WH, Han W, Zhang H, Tan X, Gu Y: EGR1 decreases the malignancy of human non-small cell lung carcinoma by regulating KRT18 expression. Sci Rep 2014, 4:5416. doi:10.1038/ srep05416.

26. Gatter K, Pezzella F: Diffuse large B-cell lymphoma. Diagn Histopathol 2010, 16(2):69-81

27. Yin QS, Wei XD, Wang XJ, Mi RH, Wang Q, Zhao HF, Zhang CJ, Li YF, Song YP: Dynamic monitoring of the T cell subpopulations diffuse large B-cell lymphoma patients with distinct gene subtypes. Leuk Lymphoma 2013, 22(3): 145-147.

28. Le Souëf PN: Gene-environmental interaction in the development of atopic asthma: new developments. Curr Opin Allergy Clin Immunol 2009, 9(2):123-127. doi:10.1097/ACl. 0b013e3283292283.

29. Kawashima M, Miossec P: mRNA quantification of T-bet, GATA-3, IFN- $\gamma$, and IL-4 shows a defective Th1 immune response in the peripheral blood from rheumatoid arthritis patients: link with disease activity. J Clin Immunol 2005, 25(3):209-214.

30. Solomou EE, Keyvanfar K, Young NS: T-bet, a Th1 transcription factor, is up-regulated in T cells from patients with aplastic anemia. Blood 2006 107(10):3983-3991.

31. Bowen H, Kelly A, Lee T, Lavender P: Control of cytokine gene transcription in Th1 and Th2 cells. Clin Exp Allergy 2008, 38(9):1422-1431. doi:10.1111/j.1365-2222. 2008.03067.x.

32. Chang CF, D'Souza WN, Ch'en IL, Pages G, Pouyssegur J, Hedrick SM: Polar opposites: Erk direction of CD4 T cell subsets. J Immunol 2012, 189(2):721-731. doi:10.4049/ jimmunol.1103015.

33. Shin HJ, Lee JB, Park SH, Chang J, Lee CW: T-bet expression is regulated by EGR1-mediated signaling in activated T cells. Clin Immunol 2009, 131(3):385-394. doi:10.1016/j.clim.2009.02.009.

34. Gordon KJ, Blobe GC: Role of transforming growth factor-beta superfamily signaling pathways in human disease. Bichim Biophys Acta 2008, 1782:197-228.

35. Bachegowda L, Gligich O, Mantzaris I, Schinke C, Wyville D, Carrillo T, Braunschweig I, Steidl U, Verma A: Signal transduction inhibitors in treatment of myelodysplastic syndromes. J Hematol Oncol 2013, 6:50. doi:10.1186/1756-8722-6-50.

36. Alshaker HA, Matalka KZ: IFN- $\gamma$, IL-17 and TGF- $\beta$ involvement in shaping the tumor microenvironment: The significance of modulating such cytokines in treating malignant solid tumors. Cancer Cell Int 2011, 11:33. doi:10.1186/1475-2867-11-33. 
37. Donkor MK, Sarkar A, Savage PA, Franklin RA, Johnson LK, Jungbluth AA, Allison JP, Li MO: T cell surveillance of oncogene-induced prostate cancer is impeded by T cell-derived TGF- $\beta 1$ cytokine. Immunity 2011, 35(1):123-134. doi:10.1016/j.immuni.2011.04.019.

38. Luo XR, Zhang Q, Liu V, Xia ZB, Pothoven KL, Lee C: Cutting Edge: TGF- $\beta$ Induced Expression of Foxp3 in T cells is Mediated through Inactivation of ERK. J Immunol 2008, 180(5):2757-2761.

39. Kanhere A, Hertweck A, Bhatia U, Gökmen MR, Perucha E, Jackson I, Lord GM, Jenner RG: T-bet and GATA3 orchestrate Th1 and Th2 differentiation through lineage-specific targeting of distal regulatory elements. Nat Commun 2012, 3:1268. doi:10.1038/ncomms 2260.

40. Stams WAG, den Boer ML, Beverloo HB, Meijerink JPP, Stigter RL, van Wering ER, Janka-Schaub GE, Slater R, Pieters R: Sensitivity to $\mathrm{L}$-asparaginase is not associated with expression levels of asparagine synthetase in $\mathrm{t}(12 ; 21)+$ pediatric ALL. Blood 2003, 101(7):2743-2747. doi:10.1182/blood-2002-08-2446.

41. Zha X, Yan X, Shen Q, Zhang Y, Wu X, Chen S, Li B, Yang L, Geng S, Weng J, Du X, Li Y: Alternative expression of TCR related genes in patients with chronic myeloid leukemia. J Hematol Oncol 2012, 5:74. doi:10.1186/17568722-5-74.

42. Shi L, Chen S, Lu Y, Wang X, Xu L, Zhang F, Yang L, Wu X, Li B, Li Y: Changes in the MALT1-A20-NF-KB expression pattern may be related to T cell dysfunction in AML. Cancer Cell Int 2013, 13(1):37. doi:10.1186/14752867-13-37.

\section{Submit your next manuscript to BioMed Central and take full advantage of:}

- Convenient online submission

- Thorough peer review

- No space constraints or color figure charges

- Immediate publication on acceptance

- Inclusion in PubMed, CAS, Scopus and Google Scholar

- Research which is freely available for redistribution 